\title{
Analytical characterization of some pasteurized apple juices during storage
}

\author{
Cristina DAMIAN*, Ana LEAHU, Mircea OROIAN and Sorina ROPCIUC \\ Stefan cel Mare University of Suceava, Faculty of Food Engineering, \\ 13 Universitatii Street, 720229, Suceava, Romania
}

\begin{abstract}
The aim of the study was to assess the effect of three weeks of storage on the chemical and rheological properties of apple juices obtained from Idared and Jonatan apples variety. Total antioxidant activity, levels of bio-active compound groups and the viscosity were measured to characterize the investigated juices. The method applied for the determination of ascorbic acid concentration was with 2, 6-diclorophenolindophenol. Total phenols (TP) in apple juices were determined using the Folin-Ciocalteau method and antioxidant activity by the use of DPPH free radical method. The viscosity of apple juices was investigated by a rotational viscometer, Brookfield viscometer (Brookfield Engineering Inc., Model RV-DV I Prime) with RV spindles. During three weeks of storage, different rates of all measured properties have been observed decreasing for both studied apples varieties juices. The juices from Jonatan apples have higher antioxidant activities that are correlated with the higher content in polyphenols and lower values of viscosity.
\end{abstract}

Keywords: antioxidant activity, apples, total phenols, ascorbic acid.

\section{Introduction}

The fruit and vegetable processing industry has evolved during the last years in response to changing consumer demand for new and safe products [1-5].

The intake of fruits and vegetables has been widely acknowledged to be inversely related to cancer incidence and cardiovascular diseases in recent epidemiological research $[6,7]$.

Fruits are low in calories and fats and are a source of natural sugars, fiber and vitamins. A good proportion of fruit and vegetables should be eaten fresh. Processed fruit and vegetables come in many forms, including: purées, cremogenate, powders, granules and juices [8]. Apples are popular fruit for consumers, owing to their good palatability as well as their nutrition and health benefits [9].

Apples are important dietary sources of phenolic compounds and have strong antioxidant capacity compared to other fruits [10-12].

Polyphenols are very important dietary antioxidants. The apples are major sources of polyphenols.

Cloudy apples juices are complex systems containing fine pulp particles dispersed in a serum constituted by macromolecules (pectins, proteins, etc.) colloidal dissolved in a true solution of low molecular weight components (sugars, organic acids, etc.) $[13,14]$.

The assurance of color stability is one of the main problems with cloudy apple juice production. Control of enzymatic browning during processing and storage is important to preserve the original appearance and nutrition of cloudy apple juice.

Enzymatic browning is caused by the action of polyphenol oxidases [15-18].

The analysis of fruit juices stability is of certain interest not only for the juice production but also for the development of new materials and composites for food packaging [19].

In this study, we added citric acid to inhibit the activity of polyphenoloxidase. In addition, citric acid has been added to prevent the phenomenon of browning.

A principal objective of the present study was to assess the effect of three weeks of storage on the physical, chemical [20] and rheological properties of apple juices. The juices were made up from Idared and Jonatan apples variety. These two varieties have been chosen to be largely grown in Suceava County. Apple juices were pasteurized on water bath at 
$90^{\circ} \mathrm{C} / 25$ minutes. The storage was developed at refrigeration temperatures $4-6^{\circ} \mathrm{C}$.

\section{Experimental}

\subsection{Plant material}

We use in this study "Idared" and "Jonatan" varieties of apples. Apples (2 kg "Idared" and $2 \mathrm{~kg}$ "Jonatan") were purchased from the local market in autumn 2013 in Suceava.

\subsection{Preparation of apple juices on a laboratory} scale

Apples (washed under cold water, peeled and the seeds removed) were grated with a special robot.

For $1500 \mathrm{~g}$ of obtained apple juices there were added $40 \mathrm{~mL}$ of citric acid $3 \%$.

Apple juices were pasteurized on water bath at $90^{\circ} \mathrm{C} / 25$ minutes.

Thereafter, the samples were cooled to $25^{\circ} \mathrm{C}$.

The apple juices were packed into glass packages, which were chosen because they are the best packaging used for fruit and vegetable juices.

The storage was developed at refrigeration temperatures $4-6^{\circ} \mathrm{C}$.

At $0,7,14$ and 21 days, the following analyzes were conducted: ascorbic acid determination, total phenols, antioxidant activity and the rheological properties (at 0, 7, 14 and 21 days).

\subsection{Ascorbic acid determination}

Determination of vitamin C [21, 22] content in pasteurized apple juices was achieved by titration with 2, 6 - diclorophenolindophenol (reagent Tillmans). The method is based on colour change of the reagent, oxidation or reduction. Thus, the ionized form of 2, 6 - diclorophenolindophenol is red in acid and blue in basic medium. Dehydroascorbic acid is obtained through reaction with vitamin $\mathrm{C}$, and after reducing the identification reactive, 4 - ( $p$-hidroxyphenil-amino $)-2,6-$ dichlorophenol. This method is commonly used, due to the fact that it is easy to use and due to the reagent sensitivity.

\subsection{Total phenols}

Total phenols [23] were determined using the Folin-Ciocalteau reagent. $10 \mathrm{~mL}$ sample was transferred to a volumetric flask, to which $5 \mathrm{~mL}$ undiluted Folin-Ciocalteau reagent was subsequently added. After $1 \mathrm{~min}, 1.5 \mathrm{~mL} 20 \%\left(\mathrm{w}^{\cdot} \mathrm{v}^{-1}\right) \mathrm{Na}_{2} \mathrm{CO}_{3}$ was added and the volume made up to $100 \mathrm{~mL}$ with $\mathrm{H}_{2} \mathrm{O}$. After $2 \mathrm{~h}$ incubation at $25^{\circ} \mathrm{C}$, the absorbance was measured at $760 \mathrm{~nm}$ and compared to a gallic acid calibration curve. Results were expressed as mg of gallic acid equivalent per $100 \mathrm{~g}$ of dry weight of sample.

2.5. 2, 2 - Di(4-tert-octylphenyl)-1-pycrilhydrazyl (DPPH) scavenging capacity assay

The method used for determining the antioxidant activity [24-27] of pasteurized apple juices is based on scavenging 2, 2-di(4-tertoctylphenyl)-1-picrylhydrazyl (DPPH) radicals. The decrease in absorbance was measured at $515 \mathrm{~nm}$ against a blank without extract, using a spectrophotometer. All determinations were performed using a T70 UV/VIS Spectrometer, PG Instruments Ltd and was made in triplicates. The final results were expressed in $\mu \mathrm{M}$ Trolox/L.

\subsection{Determination of rheological properties}

Viscosity measurements were carried out on the apple juice samples at ambient temperature $\left(25^{\circ} \mathrm{C}\right)$, with a Brookfield viscometer (Brookfield Engineering Inc, Model RV- DV II Pro+) at 2,5; 5; 10; 20; 50; and $100 \mathrm{rpm}$ with RV spindle (RV3, RV4, RV5, RV6 type). The spindle was used in accordance with the sample nature.

Each measurement was done in triplicate on the sample.

\subsection{Statistics}

Samples were assayed in triplicate and results are given as averages \pm SD. Student's test was used for the statistical evaluation and $p<0.05$ was considered statistically significant.

\section{Results and Discussions}

\subsection{Evaluation of ascorbic acid content of cloudy apple juices}

In some juices the ascorbic acid degradation is predominantly aerobic (due to the presence of dissolved oxygen), but in absence of oxygen the ascorbic acid decomposition continues anaerobically, being especially influenced by temperature. The loss of ascorbic acid is fast in the early stage of fruit juice storage, coincident with the consumption of dissolved oxygen, and then becomes gradual [28]. 
The ascorbic acid values of apple juices during storage are indicated in Table 1 . The greatest reductions of ascorbic acid concentration was registered in first week (Day 7), followed by the three week (Day 21) and second week (Day 14).

Table 1. Evaluation of ascorbic acid content in apple juices during storage

\begin{tabular}{|c|c|c|c|c|}
\hline \multirow{2}{*}{ Sample } & \multicolumn{4}{|c|}{ Ascorbic acid mg/100 g } \\
\cline { 2 - 5 } & Day 1 & Day 7 & Day 14 & Day 21 \\
\hline IDARED & $10.4 \pm 0.4$ & $8.3 \pm 1.2$ & $7.8 \pm 0.5$ & $6.2 \pm 0.6$ \\
\hline JONATAN & $10.2 \pm 1.2$ & $8.7 \pm 2.1$ & $8.2 \pm 1.2$ & $7.2 \pm 1.2$ \\
\hline
\end{tabular}

Values are means \pm standard deviation, $n=3$

\subsection{Determinations of total phenols}

The total phenolic content was expressed as gallic acid equivalents (GAE) in $\mathrm{mg} / 100 \mathrm{~g}$ fresh weight $(\mathrm{FW})$ of the fruit juices and is presented in Fig. 1. One of the main characteristics of pasteurized apple juices is a varying content of the polyphenols.

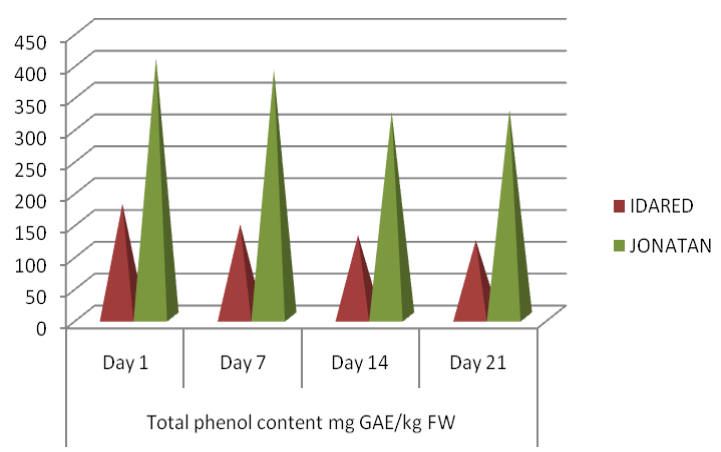

Figure 1. Total phenol content in the apple juices during three weeks of storage

The major polyphenolic groups in apples are hydroxycinnamic acids, flavan-3-ols/procyanidins, flavonols, dihydrochalcones and anthocyanins [11].

In general, we detected a decrease in the level of total phenols content, and after that the amount was more or less constant till the end of storage period. These results are in good agreement with those reported by Piretti et al. (1904) [29]. The same results were achieved by $\mathrm{Ju}$ et al. (1996), who reported a rapid decrease in the content of simple phenols in "Delicious" apples [30-32].

\subsection{Antioxidant activity}

The antioxidant activity (DPPH method) of apple juices is presented in Table 2.
Table 2. Antioxidant activity ( $\mu$ mol Trolox/L) of cloudy apple juices during storage

\begin{tabular}{|c|c|c|c|c|}
\hline \multirow{2}{*}{ Sample } & \multicolumn{4}{|c|}{ DPPH } \\
\cline { 2 - 5 } & Day 1 & Day 7 & Day 14 & Day 21 \\
\hline IDARED & $978 \pm 3.2$ & $812.3 \pm 3.4$ & $722.2 \pm 6$ & $689.2 \pm 3$ \\
\hline \multirow{2}{*}{ JONATAN } & 1201.2 & 1177.1 & 1034.2 & \\
& \pm 4.7 & \pm 5.2 & \pm 8.2 & $973.5 \pm 5$ \\
\hline
\end{tabular}

Values are means \pm standard deviation, $n=3$

The analysis of the data revealed a statistically significant difference $(p<0.05)$ between apple juices during storage.

The differences in antioxidant activity between apple juices could be preliminarily attributed to their different contents of polyphenols (Fig. 1). A significant decrease in antioxidant activity was observed for apple juices during storage. The results (Table 2) show that Jonatan juice displays significant quenching activity towards DPPH radicals, superior to that of IDARED juice (1201.2 vs 978 respectively).

A good correlation was found for the antioxidant activity of apple juices and total polyphenols $(r=$ 0.82 ). Also, the content of ascorbic acid is positively correlated with DPPH method. A lower correlation for DPPH method and ascorbic acid $(r=0.69)$ was found. Researchers often reached different conclusions on the relation of the concentration of polyphenols and the antioxidant activity in foods $[33,34]$.

\subsection{Determination of rheological properties}

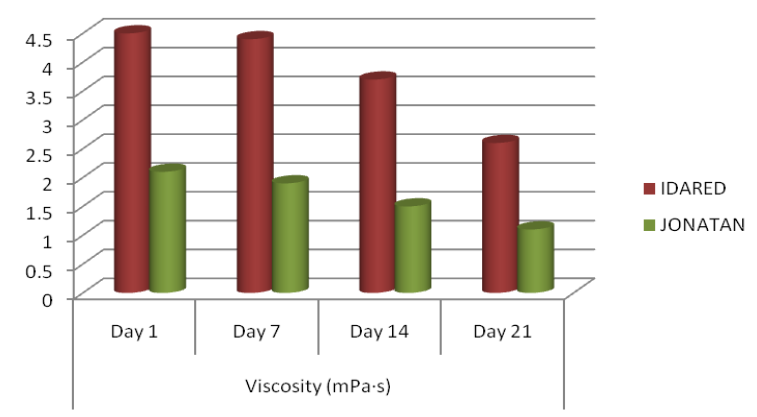

Figure 2. Viscosity of cloudy apple juices during storage

Reactions between pectins, polyphenols oxidation products and proteins caused the lower 
viscosity of the Jonatan juices [11], as we can see in Fig. 2. Thus, the Idared juices presented the highest viscosity, while the lowest viscosity was recorded by Jonatan variety.

The viscosity of apple juices, determined by Will et al. [35], was in the range from 1.74 to $2.15 \mathrm{mPa}$.

\section{Conclusions}

The storage of juice apples from Idared and Jonatan varieties has influenced the content of ascorbic acid. At the end of the analysed interval (after three weeks of storage), the ascorbic acid content has registered different rates of diminutions, depending on variety of apples.

We detected a decrease in the level of total phenol content, and after that the amount was more or less constant till the end of the storage period.

The antioxidant activity decreased significantly for apple juices during three weeks of storage.

Idared presented the highest viscosity while the lowest viscosity was recorded by Jonatan variety.

\section{References}

*E-mail address: cristinadamian@ fia.usv.ro

[1]. V. Dewanto, X. Wu, K. Adom and R. Liu, Journal of Agricultural and Food Chemistry 50, 3010-3014 (2002)

[2]. J. Ahmed, U. S. Shivhare and K. Mandeep, International Journal of Food Properties 5, 359-366 (2002)

[3]. S. Porretta, A., Birzi, C. Ghizzoni and E. Vicini, Food Chemistry 52, 35-41 (1995)

[4]. C. Sánchez-Moreno, L. Plaza, B. De Ancos and M.P. Cano, Journal of Science and Food Agriculture 8, 171-179 (2006)

[5]. M.J. Galotto, P.A. Uloa, D. Hernández, F. Fernández-Martin, R. Gavara and A. Guarda, Packaging Technology \& Science 21, 297-308 (2008)

[6]. C. Kaur and H.C. Kapoor, International Journal of Food Science \& Technology 36, 703-725 (2001)

[7]. G.J. Kelloff, J.A. Corwell, V.E. Steele, R.A. Lubet, W.A. Malone, C.W. Boone, L. Kopelovich, E.T. Hawk, R. Lieberman, J.A. Lawrence, I. Ali and C.C. Sigman, Journal of Nutrition 130, 467S-471S (2000)
[8]. O.V. Nistor, S.A. Ciorîță, E. Botez, D.G. Andronoiu, and G.D. Mocanu, Journal of Agroalimentary Processes and Technologies 16, 216-221 (2010)

[9]. J. Bizjak, A. Slatnar, F. Stampar, and R. Veberic, Food Science and Technology International 18, 569-577 (2012)

[10]. L. Massini, D. Rico, A.B. Martín Diana, and C. Barry-Ryan, European Jounal of Food Research \& Review 3, 1-15 (2013)

[11]. J. Kolniak-Ostek, J. Oszmiański, and A. Wojdylo, European Food Research and Technology 236, 777-798 (2013)

[12]. H. Dietrich, A. Rechner, C.D. Patz, R. Bitsch, V. Boehm, I. Bitsch, and M. Netzelm, Deutche Lebeensmittel-Rundschau 99, 1-11 (2003)

[13]. K. Wucherpfennig, H. Dietrich, K. Kanzler, and F. Will, Confructa Studien 31, 80-96 (1987)

[14]. T. Beveridge, Critical Reviews in Food Science and Nutrition 42, 317-337 (2002)

[15]. G. Krapfenbauer, M. Kinner, M. Gössinger, R. Schonlechner, and E. Berghofer, Journal of Agricultural and Food Chemistry 54, 54535460 (2006)

[16]. S. Guyot, C. Le Bourvellec, N. Marnet and J.F. Drilleau, LWT- Food Science and Technology 35, 289-291 (2002)

[17]. D.L. McKenzie and T. Beveridge, Food Microstructure 7, 195-203 (1988)

[18]. G.P. Zemel, C.A.Sims, M.R. Marschall, and M. Balaban, Journal of Food Science 55, 562563 (1990)

[19]. S. Brachmann, Dissertation zur Erlangung des Doktorgrades der Rheinischen FriedrichWilhelms-Universität, Bonn (2008)

[20]. A. Dumbrava, S. Birghila, and I. Enache, Ovidius University Annals of Chemistry 19, 19-26 (2008)

[21]. C. Damian, A. Leahu, and M.A. Oroian, International Conference "Modern Technologies in the Food Industry”, Chisinau, Republic of Moldova, 1-3 November (2012)

[22]. N. Matei, S. Dobrinaș, and G.L. Radu, Ovidius University Annals of Chemistry 21, 174-179 (2012)

[23]. L. Drăghici, G. Râpeanu, and T. Hopulele, Ovidius University Annals of Chemistry 22, 15-20 (2011) 
[24]. Simona Dobrinas, Emilia Stadler and Elisabeta Chirila, Ovidius University Annals of Chemistry 19, 30-33 (2008)

[25]. A. Căta, M.N. Ștefănuţ, C. Tănasie and R. Pop, Ovidius University Annals of Chemistry 21, 15-19 (2010)

[26]. G. Stanciu, E. Chirilă, S. Dobrinaş and T. Negreanu-Pirjol, Revista de Chimie, Bucharest 61, 45 (2010)

[27]. C. Damian, A. Leahu, M. Oroian, M. Avramiuc and N. Carpiuc, International Scientific Symposium: Modern Animal Husbandry-Strategies, Opportunities and Performance, Iasi, Romania (April, 2013) (unpublished results)

[28]. M. Avramiuc, A. Leahu, C. Damian and C.E. Hretcanu, Food and Environment Safety Journal of Faculty of Food Engineering, Stefan cel Mare University - Suceava XI, 81 - 86 (2012)

[29]. M.V. Piretti, G. Gallerani and G.C. Pratella, Postharvest Biology and Technology 4, 213224 (1994)
[30]. Z. Ju, Y. Juan, S. Zhan and M. Wang, Postharvest Biology and Technology 8, 83-93 (1996)

[31]. C.A. Rice-Evans, N.J. Miller and G. Paganga, Trends in Plant Science 2, 152-159 (1997)

[32]. Alessandra Francini and Luca Sebastiani, Antioxidants 2, 181-193 (2013)

[33]. R. Tsao, R. Yang, J.C. Young and H. Zhu, Journal of Agricultural and Food Chemistry 51, 6347-6353 (2003)

[34]. J. Sun, Y.F. Chu, X. Wu and R.H. Liu, Journal of Agricultural and Food Chemistry 50, 74497454 (2002)

[35]. F. Will, M. Roth, M. Olk, M. Ludwig, K. Otto and H. Dietrich, International Journal of Food Science \& Technology 41, 2057-2063 (2008)

Received: 28 January 2015 Received in revised form: 10 May 2015 Accepted: 18 May 2015 